Asy Syar'iyyah: Jurnal Ilmu Syariah dan Perbankan Islam - ISSN 2089-7227 (p) 2598-8522 (e)

Vol. 3, No. 2, Desember 2018, pp.63 - 81

\title{
FAKTOR PENYEBAB TIMBULNYA KEPATUHAN MASYARAKAT TERHADAP HUKUM (LEGAL OBEDIENCE)
}

\author{
Tauratiya \\ IAIN Syaikh Abdurrahman Siddik Bangka Belitung
}

\begin{abstract}
This study aims to determine the factors causing the emergence of public compliance with the law, through studies and analysis of a variety of literature both print and from various other social media. Community compliance with the law can essentially be interpreted as loyalty from the community as a legal subject that is realized through actions or behaviors that comply with existing law.

Based on the results of the study, the authors conclude that there are two factors causing the emergence of community compliance with the law, namely internal and external factors. Internal factors are encouragement from within an individual that makes him obey the law without coercion from any party. Internal factors can be in the form of an individual's awareness of the benefits of the law, the belief that the law is made to realize a common goal, and other things that arise from the individual. While external factors can be interpreted as factors that encourage individuals to comply with laws that come from outside the individual self. External factors can include rewards, coercion, threats and other things that come from outside the individual.
\end{abstract}

Keywords: Factor, Obedience, Law 


\section{Pendahuluan}

"Negara Indonesia adalah Negara hukum" merupakan isi dari Pasal 1 ayat (3) UUD 1945 yang menjadi bukti nyata bahwa hukum menjadi aspek penting untuk mewujudkan kondisi yang aman, nyaman, dan memberikan rasa adil pada masyarakat. Akan tetapi, dewasa ini banyak orang atau pihak-pihak yang berkepentingan didalamnya melakukan penyimpangan terhadap fungsi hukum, bahkan terkadang ada yang menganggap bahwa keberadaan hukum di masyarakat tidaklah penting. Jika dipandang dari sudut sosiologi hukum, maka para pihak atau orang-orang yang melakukan penyimpangan dan pelanggaran terhadap hukum ini dianggap tidak memiliki kesadaran hukum, tidak paham hukum, bahkan tidak patuh pada hukum.

Berbicara tentang kepatuhan atau ketaatan masyarakat pada hukum, maka hal ini akan didasarkan pada tingkat kesadaran hukum yang dimiliki seseorang terhadap hukum yang ada dan berlaku saat ini (ius constitutum), maupun hukum yang diharapkan akan ada atau yang di cita-citakan dimasa mendatang (ius constituendum). Dengan kesadaran hukum yang dimiliki masyarakat ini lah akan menjamin dipatuhinya atau ditaatinya suatu peraturan hukum. Arti kesadaran dalam hal ini ialah keadaan dimana seseorang mengetahui, mengerti, memahami dan merasa, misalnya tentang kehendak dari dibuatnya suatu aturan hukum dan lainnya. ${ }^{1}$

Terdapat tiga tindakan yang dapat dilakukan sebagai usaha untuk meningkatkan dan membina kesadaran dan kepatuhan terhadap hukum, yaitu tindakan represif, tindakan preventif dan tindakan persuasive.

1. Tindakan represif merupakan upaya penanggulangan terhadap pelanggaran norma-norma social dan harus bersifat radikal dan tegas, dalam arti bahwa penegak hukum harus lebih tegas dan bertanggung jawab dalam melaksanakan penegakan hukum atau law

\footnotetext{
${ }^{1}$ Widjaya, Kesadaran Hukum Manusia dan Manusia Pancasila, (Jakarta: Era Swasta, 1984),
} hlm. 14 
enforcement, sekaligus meningkatkan dan memperketat pengawasan terhadap penegak hukum dalam melaksanakan tugasnya. Semakin mundurnya pelaksanaan penegakan hukum maka akan berdampak pada rendahnya kesadaran terhadap hukum.

2. Tindakan preventif ialah upaya untuk mencegah terjadinya pelanggaran terhadap hukum dan rendahnya tingkat kesadaran hukum. Salah satu cara pencegahannya dengan memperberat sanksi atau hukuman tarhadap para pelanggar hukum tertentu. Selain itu, kepatuhan atau ketaatan terhadap hukum oleh individu atau masyarakat selalu diawasi dengan ketat.

3. Tindakan persuasive merupakan tindakan mempengaruhi, mendorong, mengajak, membimbing. Kepatuhan hukum memiliki kaitan erat dengan kesadaran hukum, sedangkan menanamkan kesadaran hukum sama halnya dengan menanamkan nilai-nilai kebudayaan, karena hukum adalah produk kebudayaan. Apabila sebuah Negara konsisten untuk membangun Negara hukum, artinya setiap orang tanpa terkecuali harus tunduk pada hukum yang ada. Hukum harus menegakan kebenaran dan keadilan dan tidak boleh diskriminatif, tidak memandang dan memihak apapun dan siapapun. Maka dari itu, kewibawaan hukum harus terjaga dalam hal supremasi $^{2}$ hukum agar individu atau masyarakat tetap menghormatinya melalui tindakan patuh atau taat pada hukum yang ada.

Oleh sebab itu, perlunya membentuk dan mendirikan budaya hukum menjadi hal yang mutlak pada sebuah Negara hukum, dimana hukum dituntut mampu merubah individu atau masyarakat menjadi lebih baik, teratur, dan dapat

2 Supremasi hukum adalah tindakan menegakkan dan memposisikan hukum pada tempat tertinggi dari segala-galanya 
dipercaya dalam memperjuangkan hak dan keadilan, serta memberikan rasa aman dan damai.

Kesadaran akan kemanfaatan hukum menjadi salah satu penunjang kepatuhan hukum, dan menimbulkan kesetiaan pada diri individu terhadap nilai-nilai hukum yang berlaku pada kehidupan bermsayarakat, yang kemudian direalisasikan melalui tindakan nyata untuk patuh terhadap hukum itu sendiri sehingga akan tampak dan dapat dirasakan oleh setiap masyarakat. Jadi, kepatuhan terhadap hukum pada hakekatnya dapat diartikan sebagai kesetiaan dari masyarakat sebagai subyek hukum yang diwujudkan melalui tindakan atau prilaku mematuhi hukum yang ada.

Apabila kita gunakan salah satu penafsiran hukum yaitu argumentum a contrario untuk melihat kesetiaan masyarakat terhadap hukum, maka penyebab individu atau masyarakat tidak mematuhi hukum dikarenakan adanya dua tuntutan kesetiaan terhadap suatu hal, dihadapkan sekaligus dan saling bertentangan. Misalnya kesetiaan terhadap kepentisngan pribadi individu yang bertentangan dengan kesetiaan terhadap hukum yang ada, contohnya pelanggaran lalu lintas yang sering dan dianggap lazim terjadi di masyarakat, perbuatan anarkisme, korupsi dan lain-lain, terlebih masyarakat beranggapan bahwa hukum sama sekali tidak memiliki wibawa lagi. Oleh karena itu, kepentingan pribadi, rasa ego dan tindakkan sesuka hati inilah yang menjadi pemicu individu mengabaikan bahkan mengingkari suatu hukum yang berlaku.

Dalam hal ini hukum yang dimaksudkan yaitu hukum tertulis atau hukum yang di kodifikasikan. Di Indonesia, dikatakan sebagai hukum tertulis ialah peraturan perundang-undangan yang mengikat universal dan memiliki kekuatan berlaku atau rechtsgeltung ${ }^{3}$. Suatu peraturan hukum atau undang-

3 Rechtgeltung artinya berbicara mengenai bagaimana suatu aturan hukum dapat berlaku dalam penyelenggaraan negara. 
undang dikatakan memenuhi syarat formal dan berlaku apabila telah mempunyai kekuatan berlaku:

\section{Sosiologis (Soziologische Geltung);}

Dasar kekuatan berlakunya suatu perundang-undangan secara sosiologis disini ialah bahwa diterimanya suatu hukum atau undang-undang didalam masyarakat tidak melihat peraturan itu terbentuk menurut persyaratan formal yang ditentukan atau tidak, melainkan manfaat dari peraturan tersebutlah yang lebih diperhatikan. Seperti yang ditegaskan oleh J. Bentham, bahwa "Hukum barulah akan diakui sebagai hukum, apabila hukum tersebut dapat memberikan kemanfaatan yang sebesar-besarnya kepada masyarakat secara umum". ${ }^{4}$ Hal ini dapat disimpulkan bahwa hukum yang diberlakukan harus memberikan manfaat besar bagi masyarakat tanpa memandang strata atau status social seseorang.

\section{Filosofis (Filosofische Geltung).}

Hukum atau suatu peraturan perundang-undang yang berlaku di dalam masyarakat harus menjunjung dan memperjuangkan nilai keadilan dan kesejahteraan sebagaimana terkandung dalam sila-sila pancasila, misalnya seperti nilai yang terkandung pada sila ke lima "keadilan sosial bagi seluruh rakyat Indonesia". Keadilan merupakan hal penting yang harus diperjuangkan hukum, karena dibuat dan diberlakukannya suatu aturan hukum di dalam masyarakat agar tercapai keadilan dalam hidup bermasyarakat sebagaimana semangat Pancasila dan Pembukaan Undang-Undang Dasar 1945.

${ }_{4}$ Achmad Ali, Menguak Teori Hukum Legal theory dan Teori Peradilan Judicialprudance, (Makasar: Penerbit Kencana 2007), hlm. 76. 


\section{Yuridis (Juristische Geltung);}

Suatu peraturan perundang-undangan dikatakan memiliki kekuatan berlaku secara yuridis apabila terpenuhinya syarat formal pembentukan suatu peraturan perundang-undangan.

Suatu aturan hukum akan dapat diterima masyarakat apabila memenuhi empat ciri khas hukum yang baik, sebagaimana dikemukakan oleh Prof. Satjipto Rahardjo, yaitu:

1. Memiliki sifat terbuka :

Ciri khas hukum dengan sifat terbuka mempunyai hubungan lebih luas yang terjalin secara timbal balik, dimana hukum dianggap sebagai kesatuan unsur antara peraturan dan penetapan, yang mendapat pengaruh besar dari faktor sejarah, social, ekonomi, budaya, dan sebagainya. Sebaliknya, sistem hukum pun memberikan pengaruh pada faktor-faktor diluar sistem hukum tersebut. System hukum Indonesia dikatakan terbuka karena aturanaturan hukum yang dibuat terbuka untuk ditafsirkan berbeda, dan oleh sebab itu aturan hukum selalu mengalami perkembangan.

2. Diawali dengan pemberitahuan :

Adanya pemasyarakatan dari pemerintah terhadap aturan hukum yang dibuat dengan cara penyebar luasan melalui media televisi, radio, media cetak, dan lainnya.

3. Sasarannya pasti :

Sasaran pembentukan suatu peraturan perundang-undangan ditujukan secara pasti untuk masyarakat.

4. Mengatasi gejolak masalah :

Aturan hukum yang dibuat menangani permasalahan di dalam masyarakat, dan memberikan sanksi atau hukuman bagi pelanggarnya. 


\section{Metode Penelitian}

Penelitian ini merupakan penelitian yuridis normatif, yaitu penelitian hukum yang menggunakan literature sebagai sumber data atau dikenal pula sebagai penelitian kepustakaan. ${ }^{5}$ Pendekatan yang digunakan dalam penelitian ini adalah hukum sosiologis, yang berfokus pada penelitian efektivitas hukum, penelitian berlakunya hukum, penelitian terhadap identifikasi hukum tidak tertulis, dan penelitian dampak hukum. ${ }^{6}$

Data utama penelitian ini berupa bahan-bahan kepustakaan yang terdiri dari Undang-Undang, literature, buku-buku lain yang berkaitan dengan penelitian ini, yaitu meliputi:

a) Bahan Hukum Primer

Bahan hukum primer berupa peraturan perundang-undangan atau peraturan lain yang memiliki kekuatan mengikat dan bersifat autoritatif. 7

b) Bahan Hukum Sekunder

Bahan hukum sekunder berupa artikel ilmiah, buku-buku ilmu hukum yang memberikan penjelasan mengenai bahan hukum primer. 8

c) Bahan Hukum Tersier

Bahan hukum tersier berupa kamus hukum, ensiklopedia, dan sebagainya yang menjelaskan bahan hukum primer dan sekunder. ${ }^{9}$

5 Soerjono Soekanto dan Sri Mamudji, Penelitian Hukum Normatif, (Jakarta: PT. Raja Grafindo Persada, 2001), hlm. 13.

6 Amiruddin dan Zainal Asikin, Pengantar Metode Penelitian Hukum, (Jakarta: PT. RajaGrafindoPersada, 2012), hlm.133-162.

7 Peter Mahmud Marzuki, Penelitian Hukum, (Jakarta: Kencana, 2005), hlm. 140.

${ }^{8}$ Amiruddin dan Zainal Asikin, Op. Cit., hlm. 32.

${ }^{9}$ Mukti Fajar ND dan Yulianto Achmad, Dualisme Penelitian Hukum Normatif dan Empiris, (Yogyakarta: Pustaka Pelajar, 2010), hlm .157-158. 


\section{Pembahasan}

Untuk membangun budaya hukum di Indonesia, tingkat kepatuhan terhadap hukum menjadi hal yang substansial. Kepatuhan manusia terhadap hukum dikarenakan hukum dijadikan suatu kebutuhan, hal ini ditegaskan dengan istilah "Ubi Societas Ibi Ius" yang dapat diartikan dimana ada masyarakat, maka disitu ada hukum. Dari istilah hukum ini dapat ditarik kesimpulan bahwa setiap individu membutuhkan hukum untuk menjalankan kehidupannya, karena setiap individu atau masyarakat jelas mengharapkan kehidupan yang tentram, aman, nyaman, dan melalui hukum lah kehidupan tersebut dapat diwujudkan. Terdapat tiga bentuk perilaku dalam kepatuhan, yaitu: 10

1. Conformity atau konformitas, individu membarui sikap dan prilaku mereka karena pengaruh sosial agar sesuai dengan kaidah sosial yang berlaku.

2. Compliance atau penerimaaan, merupakan keinginan seseorang bersedia disugesti dengan komunikasi persuasif dari orang yang disukai atau berpengetahuan luas, serta karena rasa percaya terhadap kaidah social yang ada dalam masyarakat atau kelompok maka tindakannya pun dilakukan dengan senang hati.

3. Obedience atau ketaatan, adalah bentuk kesediaan untuk menyerahkan diri sepenuhnya dan tunduk pada hukum atau perintah yang dibuat pihak berwewenang sebagai suatu hal yang benar.

${ }_{10}$ Perpustkaan Universitas Negeri Islam Sultan Syarif Kasim, "Kepatuhan Terhaadap Norma-norma Sosial", Situs: Repisitory.uin.suska.ac.id/1116/3/BAB\%20\%2011.pdf, diakses 26 november 2018 Pukul 13.30 WIB. 


\section{A. Faktor Seseorang Mematuhi Hukum}

Kepatuhan hukum dapat didefinisikan sebagai kesadaran kemanfaatan hukum yang menimbulkan kesetiaan terhadap nilai-nilai hukum dalam kehidupan bermasyarakat, selanjutnya diwujudkan dalam bentuk prilaku atau tindakan.

Robert Biersted dalam bukunya The Social Order menegaskan bahwa proses kepatuhan seseorang terhadap suatu aturan hukum terjadi karena beberapa faktor, yaitu: Pertama, kepatuhan terhadap hukum ditanamkan pada diri seseorang secara sengaja (Indoctrination), dengan kata lain sebuah aturan hukum menjadi doktrin yang secara sengaja ditanamkan pada masyarakat dengan tujuan agar penerapan hukum merata sampai pada lapisan masyarakat dan kepatuhan hukum yang diinginkan dapat terwujud.

Faktor kedua, kepatuhan hukum karena pembiasaan perilaku (Habituation), yaitu patuhnya seseorang pada aturan hukum karena sudah terbiasa dan merupakan rutinitas yang mereka lakukan, misalnya seseorang menggunakan helm pada saat berkendaraan karena sudah terbiasa dan merasa tidak nyaman ketika tidak menggunakan helm saat berkendaraan.

Faktor ketiga, pemanfaatan dari aturan hukum yang dipatuhi (Utility), yaitu seseorang patuh terhadap hukum karena dapat memanfaatkan secara substantive dari aturan tersebut. Faktor keempat, mengidentifikasikan dalam suatu kelompok tertentu (Group Indentification) yaitu patuhnya seseorang terhadap aturan atau suatu hukum apabila telah melihat kelompok lainnya mematuhi atau melaksanakan aturan tersebut. Akan tetapi, perlu diperhatikan pula, meskipun suatu norma atau aturan telah disosialisasikan tidak menjamin norma atau aturan tersebut dapat diterima dan tertanam pada diri suatu masyarakat. 
Ernst Utrecht menjelaskan bahwa ada beberapa penyebab seseorang mematuhi hukum, yaitu:

1. Seseorang memiliki kepentingan terhadap berlakunya suatu peraturan atau hukum tersebut. Misalnya, dengan mematuhi suatu peraturan, seseorang akan merasa aman berada di lingkungannya. ${ }^{11}$

2. Keharusan untuk menerima suatu aturan atau hukum agar terciptanya rasa tentram dalam dirinya, atau dengan kata lain seseorang memilih untuk mematuhi aturan demi menghindari kesulitan dalam hidupnya.

3. Menjadi kehendak dari diri sendiri untuk mematuhi aturan atau hukum, karena umumnya hukum akan dirasa ada ketika kepentingannya dibatasi oleh suatu aturan hukum yang ada.

4. Patuhnya seseorang terhadap suatu aturan dikarenakan adanya paksaan atau sanksi social yang akan diterima apabila tidak patuh atau melanggar aturan tersebut.

Sementara itu, Soerjono Soekanto menjelaskan bahwa patuhnya seseorang terhadap hukum tidak terjadi begitu saja, akan tetapi ada proses atau tahapan yang dilalui, yaitu: ${ }^{12}$

1. Tahap prakonvensional, dimana pada tahap pertama ini seseorang patuh terhadap aturan atau hukum karena memperhatikan akibat apabila tidak mematuhinya. Tahap ini meliputi:

a) Tahap kekuatan fisik. Seseorang patuh terhadap hukum untuk menghindari penjatuhan sanksi negative atau hukuman, karena baginya sanksi atau hukuman tersebut dianggap sebagai suatu siksaan fisik belaka. Hal ini berakibat pada proses penegakan hukum yang harus selalu diawasi oleh petugas hukum.

11 Ernst Utrecht, Pengantar Hukum Administrasi Negara Indonesia Cet VI, (Jakarta. Penerbit dan Balai Buku Ichtiar, 1963).

12 Soerjono Soekanto, Faktor-faktor yang Mempengaruhi Penegakan Hukum, (Jakarta : Raja Grafindo Persada, 2004), hlm.8 
Kepatuhan hukum yang tahap ini merupakan tingkat paling rendah.

b) Tahap Hedonistic. Patuh atau tidaknya individu terhadap hukum didasari untuk kepuasan dirinya sendiri yang semata-mata bersifat emosional belaka.

2. Tahap Konvensional. Inti dari tahap ini difokuskan pada pengakuan bahwa hukum berisikan aturan dan harus selalu ditegakan dalam pergaulan hidup bermasyarakat. Tahap ini terbagi menjadi dua, yaitu:

a) Tahap interpersonal. Kepatuhan seseorang terhadap hukum bertujuan untuk menjaga hubungan baik dan menyenangkan orang lain. Tahap ini berlangsung antar individu yang memiliki kepentingan satu sama lain. Selama hubungan antar pihak terjaga dengan baik dan kepentingan antar pihak terpenuhi maka kepatuhan terhadap hukum dapat terjaga. Begitu pula sebaliknya, apabila kepentingan antar pihak sudah tidak ada maka hukum tidak berlaku lagi atau akan timbul ketidakpatuhan hukum.

b) Tahap hukum dan ketertiban. Hukum dapat dipatuhi apabila penegak hukum memiliki kekuasaan dan wewenang. Oleh karena itu, pada tahap ini kekuasaan dan wewenang berperan penting dalam menimbulkan rasa patuh terhadap hukum.

Berdasarkan tahapan yang dilalui, hukum dapat digunakan sebagai sarana guna mewujudkan cita-cita bersama. Oleh sebab itu, hukum dapat dipatuhi karena hukum adalah konkretisasi nilai-nilai yang berlaku ditengah masayarakat demi mewujudkan cita-cita yang diharpakan bersama. 
Dengan demikian, kepatuhan hukum merupakan konsepsi dalam diri manusia yang bersifat abstrak berkenaan dengan keselarasan antara ketertiban dengan ketentraman yang diharapakan atau yang sepatutnya. ${ }^{13}$

Kutschincky merumuskan faktor-faktor yang melandasi kepatuhan hukum, yaitu law awareness, law acquaintance, legal attitude, dan legal behavior. Law awareness ialah pengetahuan mengenai peraturan hukum, law acquaintance ialah pengetahuan mengenai isi peraturan hukum, legal attitude ialah sikap terhadap peraturan hukum, dan legal behavior diartikan sebagai pola-pola perikelakuan hukum. ${ }^{14}$

Disisi lain, Zainudin Ali mengungkapkan bahwa kepatuhan masyarakat terhadap hukum dilandasi oleh seberapa baik ketentuan/aturan hukum diketahui, dipahami, dan dihargai masyarakat. Dengan kata lain masyarakat yang memahami aturan hukum cenderung lebih patuh dibandingkan yang sekedar mengetahui. Hal ini dikenal dengan legal consciousness atau knowledge and opinion about law..$^{15}$

\section{B. Jenis Kepatuhan}

H. C Kelmaan mengemukaakan beberapa jenis kepatuhan terhadap suatu aturan hukum, yaitu kepatuhan yang bersifat compliance, identification, internalization. ${ }^{16}$

1. compliance, merupakan kepatuhan pada hukum yang didasarkan pada keinginan mendapatkan suatu imbalan penghargaan, sekaligus usaha individu untuk menghindar dari sanksi yang akan dikenakan. Kepatuhan yang dimaksud tidak didasarkan pada tujuan norma atau kaedah hukum itu sendiri, melainkan lebih dititik beratkan pada alat-

${ }^{13}$ Ibid

${ }^{14}$ Ibid, hal. 159.

${ }^{15}$ Zainuddin Ali. Filsafat Hukum. (Jakarta: Sinar Grafika, 2007)

16 Soerjono Soekanto, Kesadaran Hukum dan Kepatuhan Hukum, (Jakarta : Rajawali Pers. 1982). Hlm. 49-50. 
alat kendali pihak penguasa, hal ini mengakibatkan kepatuhan individu akan tampak apabila pelaksanaan kaidah hukum diawasi dengan ketat.

2. Identification, merupakan kepatuhan pada hukum bukan karena nilai instrinsiknya, tetapi dikarenakan rasa takut terhadap hubungan baiknya dengan seseorang menjadi buruk. Melalui kepatuhan, seseorang dapat menjaga hubungan keanggotaannya.

3. Internalization, merupakan kepatuhan seseorang dikarenakan secara hakikatnya kepatuhan tersebut memberikan balasan penghargaan atau imbalan. Individu mematuhi hukum dengan baik didasarkan atas kesadaran dalam diri yang membuatnya.

Pada kenyataannya, seorang individu atau masyarakat akan patuh pada hukum karena salah satu dari ketiga jenis sifat di atas, seperti taat karena identification dan tidak masuk dalam jenis compliance dan internalization, atau seseorang mematuhi hukum berdasarkan dua jenis bahkan tiga jenis kepatuhan sekaligus, tergantung pada kondisi dan situasi yang ada.

\section{Faktor Penyebab Timbulnya Kepatuhan Masyarakat Terhadap Hukum}

Secara umum, alasan timbulnya kepatuhan hukum individu dalam masyarakat antara lain: ${ }^{17}$

a. Keterkaitan pembuatan suatu aturan hukum dengan hukum yang dibutuhkan oleh individu atau masyarakat kemudian menjadi tujuan aturan hukum secara universal itu.

17 Achmad Ali, Menguak Teori Hukum (Legal Theory) dan Teori Peradilan (Judicialprudence) Termasuk Interpretasi Undang-Undang (Legisprudence), (Jakarta: Penerbit Kencana, 2015), hlm. 376. 
b. Kejelasan kandungan pokok aturan hukum, sehingga lebih mudah untuk dipahami dan diterima oleh masyarakat dimana aturan hukum tersebut diberlakukan.

c. Pemasyarakatan secara optimal terhadap aturan hukum yang dibuat pada sasaran aturan hukum oleh pemerintah.

d. Apabila aturan hukum yang dibentuk adalah suatu peraturan perundang-undangan, maka sebaiknya aturan tersebut bersifat melarang bukan bersifat mengharuskan, hal ini dikarenakan hukum dengan sifat melarang lebih dilaksanakan dibandingkan dengan hukum dengan sifat mengharuskan.

e. Pemberian sanksi pelanggaran terhadap suatu aturan hukum maka disesuaikan dengan tingkatan aturan hukum yang dilanggar.

f. Tingkatan pemberian sanksi harus sebanding dengan aturan hukum yang dilanggar, serta dapat dilaksanakan.

g. Adanya pelanggaran terhadap suatu aturan hukum memungkinkan penegak hukum (Polisi, Jaksa, Hakim, dan lainnya) untuk menangani pelanggaran tersebut. Hal ini dikarenakan tindakan pelanggaran tersebut merupakan tindakan yang riil, nyata, dapat diamati, substansial, dan mempunyai sanksi jelas dan tegas, sehingga mengharuskan untuk diproses melalui setiap tahapan, yang antara lain yaitu proses penyelidikan, proses penyidikan, proses penuntutan, dan proses penghukuman.

h. Kaidah moral yang terkandung dalam suatu aturan hukum berwujud larangan jauh lebih efisien dan efektif, dibandingkan dengan aturan yang bertentangan dengan moral individu atau masyarakat yang menjadi sasaran diberlakukannya hukum tersebut.

i. Dalam menegakan suatu aturan hukum agar efektif di dalam masyarakat dibutuhkan peran penegak hukum yang optimal dan professional. 
j. Standar hidup minimal terkait sosio-ekonomi masyarakat juga menjadi salah satu syarat bagi aturan hukum agar berlaku efektif di dalam masyarakat.

Terkait hal ini, Howard dan Mumnres berbeda pendapat, menurutnya yang dikaji dalam hal ini bukanlah ketaatan terhadap hukum secara luas, sebaliknya kataatan terhadap suatu aturan hukum yang sempit atau khusus saja. Sedangkan, Achmad Ali mengemukakan pendapatnya bahwa kajian terhadap aturan hukum dilakukan secara luas dan sempit, dengan mempertanyakan kepatuhan terhadap aturan hukum secara umum dan terhadap aturan hukum yang khusus, serta apa saja yang menjadi faktor-faktor yang mempengaruhinya. 18

Beberapa ahli mengemukakan pendapat yang berbeda tentang faktor yang mempengaruhi kepatuhan hukum. Taylor berpendapat bahwa kepatuhan terhadap aturan dapat terbentuk berdasarkan beberapa faktor yaitu:19

1. Informasi. Seseorang cenderung patuh terhadap suatu aturan apabila mendapat informasi yang cukup mengenai aturan tersebut. Pengetahuan dan pemahaman mengenai peraturan dapat menimbulkan rasa kesadaran akan pentingnya peraturan yang dibentuk demi mencapai tujuan bersma yang diinginkan. Oleh karena itu, informasi menjadi faktor utama dalam mempengaruhi kepatuhan terhadap hukum.

2. Imbalan. Kemampuan dalam memberi hal positif kepada orang lain merupakan salah satu basis kekuasaan. Hal positif tersebut dapat berupa imbalan yang menguntungkan atau bantuan ke orang lain dalam mencapai tujuan yang diharapkan. Melalui pemberian imbalan seseorang dapat patuh terhadap hukum yang berlaku karena sifatnya menguntungkan dan tidak merugikan baik personal maupun orang lain.

\footnotetext{
18 Ibid.,

19 Taylor, Psikologi Sosial, Terj. Triwibowo, (Jakarta: Erlangga, 2006)
} 
3. Keahlian. Pengetahuan atau ketrampilan khusus dapat menjadi sarana dalam mempengaruhi seseorang untuk tunduk terhadap aturan. Hal tersebut didasari oleh rasa percaya seseorang kepada ahli, karena mereka percaya bahawa melalui pengetahuan dapat membantu meraih tujuan yang diharapkan.

4. Kekuasaan rujukan. Faktor ini dilatarbelakangi ketika seseorang menjalin hubungan dengan individu atau kelompok yang memiliki kekuasaan. Seseorang akan bersedia melakukan sesuatu demi menjalin hubungan baik dengan individu atau kelompok yang memiliki kekuasaan.

5. Otoritas yang sah. Faktor keabsahan suatu otoritas dalam menerapkan aturan sehingga seseorang akan patuh selagi sesuai dengan norma yang berlaku.

6. Koersi. Koersi atau paksaan terhadap seseorang mampu menimbulkan kepatuhan seseorang terhadap aturan. Koersi dapat berupa paksaan fisik hingga ancaman sanksi/hukuman.

Sedangkan Milgram mengungkapkan bahwa terdapat 6 faktor yang mempengaruhi kepatuhan, yaitu status lokasi, tanggung jawab personal, dukungan teman, legitimasi figur otoritas, status figur otoritas, dan kedekatan figur otoritas. ${ }^{20}$ Disisi lain, Sears $\mathrm{dkk}$ mengemukakan faktor yang dapat menimbulkan kepatuhan, yaitu:21

1. Penghargaan. Melalui penghargaan dapat menstimulus seseorang agar bersedia melakukan sesuatu, oleh karena itu faktor ini menjadi salah satu metode yang efektif dalam menimbulkan kepatuhan seseorang.

2. Penekanan (hukuman dan ancaman). Selain penghargaan, hukuman dan ancaman juga menjadi faktor yang efektif dalam menimbulkan

20 D.G. Myers, Psikologi Sosial, (Jakarta: Salemba Humanika, 2014)

21 Sears, David O., Freedman, Jonathan L. \& L. Anne Peplau. (1985). Psikologi Sosial. (Alih bahasa: Michael Adryanto). Jakarta: Penerbit Erlangga. 
kepatuhan seseorang. Pemberian hukuman bagi pelanggar dan ancaman bagi orang yang hendak melanggar dapat menimbulkan rasa takut sehingga akan menimbulkan rasa patuh.

3. Otoritas yang sah. Seseorang cenderung akan mematuhi suatu aturan sesuai dengan norma sosial yang berlaku yang diperkuat oleh otoritas yang sah.

4. Harapan. Harapan dapat menimbulkan kepatuhan, hal ini didasari bahwa manusia memiliki impian/harapan akan masa depan. Pemberian harapan kepada seseorang dapat menempatkannya dalam situasi yang terkendali sehingga orang tersebut akan patuh terhadap aturan yang diberikan.

Berdasarkan beberapa pendapat ahli dapat disimpulkan bahwa kepatuhan dapat timbul dari kesadaran individu. Kepatuhan yang timbul dari kesadaran individu itu sendiri cenderung lebih efektif dan efesien. Tidak memerlukan usaha yang besar dalam membuat seseorang patuh terhadap hukum dan bersifat jangka panjang. Akan tetapi, menumbuhkan kesadaran masyarakat untuk mematuhi hukum secara merata bukan suatu hal yang mudah karena membutuhkan usaha semua elemen baik pemerintah maupun masyarakat.

\section{Kesimpulan}

Kepatuhan hukum merupakan kewajiban bagi setiap individu. Kepatuhan hukum dapat diartikan sebagai kesadaran kemanfaatan hukum yang menimbulkan kesetiaan terhadap nilai-nilai hukum dalam kehidupan bermasyarakat, selanjutnya diwujudkan dalam bentuk prilaku atau tindakan.

Secara garis besar, faktor penyebab timbulnya kepatuhan hukum dapat bagi menjadi dua bagian, yaitu faktor internal dan eksternal. Faktor internal merupakan dorongan dari dalam diri individu yang membuat ia patuh 
Tauratiya

terhadap hukum tanpa ada paksaan dari pihak manapun. Faktor internal dapat berupa kesadaran individu akan manfaat hukum, keyakinan bahwa hukum dibuat untuk mewujudkan tujuan bersama, dan hal-hal lain yang timbul dari dalam diri individu. Sedangkan faktor eksternal dapat diartikan sebagai faktor yang mendorong individu dalam mematuhi hukum yang berasal dari luar diri individu tersebut. Faktor eksternal dapat berupa imbalan, paksaan, ancaman dan hal-hal lain yang berasal dari luar diri individu. 


\section{DAFAR PUSTAKA}

Ali, Achmad. Menguak Teori Hukum (Legal Theory) dan Teori Peradilan (Judicialprudence) Termasuk Interpretasi Undang-Undang (Legisprudence). Jakarta: Penerbit Kencana, 2015.

Ali, Achmad. Menguak Teori Hukum Legal theory dan Teori Peradilan Judicialprudance. Makasar: Penerbit Kencana, 2007.

Ali, Zainuddin. Filsafat Hukum. Jakarta: Sinar Grafika, 2007.

Amiruddin \& Asikin, Zainal. Pengantar Metode Penelitian Hukum. Jakarta: PT. RajaGrafindoPersada, 2012.

Marzuki, Peter Mahmud. Penelitian Hukum. Jakarta: Kencana, 2005.

Myers, D.G.. Psikologi Sosial. Jakarta: Salemba Humanika, 2014.

ND, Mukti Fajar \& Achmad, Yulianto. Dualisme Penelitian Hukum Normatif dan Empiris. Yogyakarta: Pustaka Pelajar, 2010.

Perpustkaan Universitas Negeri Islam Sultan Syarif Kasim, "Kepatuhan Terhaadap Norma-norma Sosial", Situs: Repisitory.uin.suska.ac.id/1116/3/BAB\%20\%2011.pdf, diakses 26 november 2018 Pukul 13.30 WIB.

Sears, David O., Freedman, Jonathan L. \& L. Anne Peplau. Psikologi Sosial. (Alih bahasa: Michael Adryanto). Jakarta: Penerbit Erlangga, 1985.

Soekanto, Soerjono \& Mamudji, Sri. Penelitian Hukum Normatif. Jakarta: PT. Raja Grafindo Persada, 2001.

Soekanto, Soerjono. Faktor-faktor yang Mempengaruhi Penegakan Hukum. Jakarta : Raja Grafindo Persada, 2004.

Taylor. Psikologi Sosial. Terj. Triwibowo. Jakarta: Erlangga, 2006.

Utrecht, Ernst. Pengantar Hukum Administrasi Negara Indonesia Cet VI. Jakarta. Penerbit dan Balai Buku Ichtiar, 1963.

Widjaya. Kesadaran Hukum Manusia dan Manusia Pancasila. Jakarta: Era Swasta, 1984. 